\title{
Evaluation of protection against desiccation with different artificial tears containing $0.1 \%-0.3 \%$ hyaluronic acid in experimental dry eye model
}

Fatma Ahmed ( $\nabla$ fatma.ahmed@hotmail.de)

Universitätsmedizin Greifswald: Universitatsmedizin Greifswald https://orcid.org/0000-0002-78484901

\section{Frank Tost}

Universitätsmedizin Greifswald: Universitatsmedizin Greifswald

Rico Großjohann

Universitätsmedizin Greifswald: Universitatsmedizin Greifswald

\section{Carmen Wolke}

Universitätsmedizin Greifswald: Universitatsmedizin Greifswald

\section{Uwe Lendeckel}

Universitätsmedizin Greifswald: Universitatsmedizin Greifswald

\section{Research article}

Keywords: dry eye disease, hyaluronic acid, artificial tears, cell viability

Posted Date: October 20th, 2020

DOl: https://doi.org/10.21203/rs.3.rs-79468/v1

License: (c) (i) This work is licensed under a Creative Commons Attribution 4.0 International License. Read Full License 


\section{Abstract}

Background: Tear film instability, hyperosmolarity, ocular surface inflammation, apoptosis and neurosensory abnormalities are causes of dry eye. Lubricant target tear film instability, the most effective agent for tear film stabilization being Sodium Hyaluronate $0.1-0.3 \%$. Sodium Hyaluronate is suggested to be protective for epithelium in dry eye. To test this hypothesis, this study was performed in vitro with commercially available solutions containing hyaluronic acid (HA) in concentrations ranging from 0.1 to $0.3 \%$. To evaluate the desiccation protection capability of different Sodium Hyaluronate 0.1 to $0.3 \%$, we employed a reproducible in vitro cell culture system.

\section{Methods:}

Conjunctival (Chang 1-5c-4) and corneal cells (pRSV-T 2.040) were cultivated under standard conditions. Under confluent cell growth cells, conjunctival epithelial cell line Chang 1-5c-4 and the corneal cell line 2.040 pRSV-T were wetted for 20 min with five commercial ophthalmic solutions and one agent in trial phase (sample 1: $0.1 \% \mathrm{HA}$; sample 2: $0.3 \% \mathrm{HA}$; sample 3: $0.15 \% \mathrm{HA}, 2 \%$ dexpanthenol, sodium chloride; sample 4: $0.1 \% \mathrm{HA}$; sample 5: 0.2\% HA; sample 6: unknown, PBS as negative control, unsupplemented medium as positive control). After 20 minutes cells were exposed to continuous air flow for $0,15,30$ and 45 minutes. Assessment of viable cells was performed by alamarBlue ${ }^{\circledR}$ assay and LIVE/DEAD ${ }^{\circledR}$ Viability/ Cytotoxicity Kit.

Results: It has been shown that both cell lines showed different response to protection by the tested solutions. Greatest protection was observed at 15 minutes with most agents. Best results in protection from desiccation was assessed with sample 2 even at maximum exposure time at 45 minutes. Sample 2 showed an average survival rate of $91 \%$ at 45 minutes exposure time, whereas no significant amount of vital cells were detected after application with sample 6 . Sample 6 was the only substance that presented with early significant cell loss at 0 and 15 minutes by $35 \%$.

Conclusions: Higher concentration of Hyaluronate acid with $0.3 \%$ and an ionic composition close to the normal tearfluid seem to provide the best protective effect against desiccation in experimental dry eye.

\section{Background:}

Dry eye syndrome, predominantly affecting post-menopausal women, is a disorder of the ocular surface, resulting in irritation, pain, burning sensation, discomfort and decreased visual acuity and consecutively leading to depression and anxiety disorders. Tear film instability, hyperosmolarity, ocular surface inflammation, apoptosis and neuro-sensory abnormalities play an important role in the development of dry eye disease. One of the most effective agent for moistening of the ocular surface is the application of artificial tears with hyaluronic acid. Several experimental and clinical studies revealed the beneficial use of hyaluronic acid based artificial tears in terms of symptom control as well as causal treatment $(2-4,7$, $9,13)$. This study`s aim was to evaluate the protective effect of five commercial unpreserved ophthalmic solutions, containing various concentrations of hyaluronic acid and differing compositions in order to 
improve the current therapeutic options of dry eye syndrome. For this purpose, an in-vitro model of humanized epithelial conjunctival and corneal cells was used, to analyze the effects of the eye drops against desiccation.

\section{Methods:}

Cell cultures: Two different epithelial cell cultures were used to analyze the protection of the artificial tears against desiccation. The conjunctival cell line Chang 1-5c-4 (American Type Culture Collection) was contaminated via HeLa-cells containing human papilloma virus 18. The base medium for this cell line is Medium 199 containing 25 mM HEPES buffer, 10\% fetal calf serum and 1\% penicillin/streptomycin (all $\mathrm{GIBCO}{ }^{\circledR} /$ Thermo Fisher Scientific). The cultivation proceeded under exclusion of $\mathrm{CO}_{2}$ at a temperature of $37^{\circ} \mathrm{C}$. The $2.040 \mathrm{pRSV}$-T cells (American Type Culture Collection) derived from the human cornea were transfected with a plasmid containing SV-40 and Rous Sarcoma viral sequences. The Keratinocyte-Serum Free medium contains $5 \mathrm{ng} / \mathrm{mL}$ recombinant EGF, $0.05 \mathrm{mg} / \mathrm{ml}$ bovine pituitary extract (both GIBCO ${ }^{\circledR} /$ Thermo Fisher Scientific), $0.05 \mathrm{mg} / \mathrm{mL}$ insulin, $500 \mathrm{ng} / \mathrm{mL}$ hydrocortisone (both Sigma-Aldrich Chemie $\mathrm{GmbH}$ ) and $1 \%$ penicillin/streptomycin (GIBCO®/Thermo Fisher Scientific). At least two hours before incubation at $37^{\circ} \mathrm{C}$ and $5 \% \mathrm{CO}_{2}$, the flasks were precoated with a mixture containing $0.01 \mathrm{mg} / \mathrm{mL}$ fibronectin, $0.03 \mathrm{mg} / \mathrm{mL}$ bovine collagen type I (both Sigma-Aldrich Chemie $\mathrm{GmbH}$ ) and $0.01 \mathrm{mg} / \mathrm{mL}$ bovine serum albumin (GIBCO®/Thermo Fisher Scientific). 
The following medications were used in this study:



\section{Viability testing}

The confluent growing cells were incubated in 96-well-plates with $50 \mu \mathrm{L}$ of each sample (see Table 1) was applied on six deepenings. The same amount of PBS served as negative control, while $100 \mu \mathrm{L}$ of unsupplemented medium was the positive control. After 20 minutes, the medications were cautiously removed and the cells were exposed to a continuous air flow for $0,15,30$ and 45 minutes. To assess the amount of viable cells, the cells were again incubated for four hours at $37^{\circ} \mathrm{C}$ with a mixture containing $100 \mu \mathrm{L}$ respective medium and $10 \mu \mathrm{L}$ alamarBlue ${ }^{\circledR}$. The absorption of the oxidized form of alamarBlue ${ }^{\circledR}$ (ThermoFischer Scientific) was measured at wave length $570 \mathrm{~nm}$ and $600 \mathrm{~nm}$ using an ELISA-reader. This procedure was repeated four times, so that 24 measured values were available for each sample. To validate the results, another test, the LIVE/DEAD ® Viability/ Cytotoxicity Kit was performed. After 
exposure to continuous air flow, $100 \mu \mathrm{L}$ PBS and $100 \mu \mathrm{L}$ PBS based mixed solution composed of $2 \mu \mathrm{l} / \mathrm{mL}$ $1,5 \mathrm{mM}$ propidium iodide and $0.5 \mu \mathrm{l} / \mathrm{mL} 4 \mathrm{mM}$ Calcein AM were applied on the cells. After 20 minutes the greenly stained viable cells and redly stained dead cells could easily be identified and counted under the fluorescence microscope (Olympus IX, Scion VisiCapture).

\section{Analysis:}

The survival rate for the alamarBlue ${ }^{\circledR}$ assay was assessed using the following formula:

$$
\text { Survival rate in } \%=\frac{(E 2 \times T 1)-(\text { E1xT2 })}{(E 2 \times P 1)-(E 1 \times P 2)} \times 100
$$

E1: 80586 (molar extinction coefficient of alamarBlue ${ }^{\circledR}$, reduced at $570 \mathrm{~nm}$ )

E2: 117216 (molar extinction coefficient of alamarBlue®, oxidized at $600 \mathrm{~nm}$ )

T1: absorption of the sample at $570 \mathrm{~nm}$

T2: absorption of the sample at $600 \mathrm{~nm}$

P1: mean of absorption of positive control at $570 \mathrm{~nm}$

P2: mean of absorption of positive control at $600 \mathrm{~nm}$

\section{Data analysis:}

Statistical analysis was done by SPSS, version 24 (SPSS Inc.). For descriptive purposes, mainly boxplots with medians, quartiles and an interquartile range (IQR) $\pm 1.5 \times$ IQR with outliers as indicated (Tukey method) were used in order to present the results clearly. Statistical significance was assessed by Wilcoxon signed rank test. P values lower than 0.05 were considered to indicate significant differences.

\section{Results:}

Viable cells were significantly reduced under the influence of desiccation in all solutions. The amount of viable cells that were incubated with the samples was compared with the amount of viable cells incubated with cell medium respectively (baseline value). A decrease in cell viability for both cell lines was assessed throughout the exposure for all samples. Only sample 2 (Sodium Hyaluronate $0.3 \%$ ) imposed with a significantly higher survival of Chang and pRSV-T cells even at maximum desiccation at 45 minutes. The cells incubated with sample 6 (new unknown formulation) showed overall the lowest amount of viable cells. The greatest loss of cells with most samples was apparent between 0 and 15 minutes for conjunctival cells and between 15 and 30 minutes for corneal cells. The pRSV-T cells were more sensitive to dry air then Chang cells. 
As shown in figure 1, sample 4 and 5 had the greatest effect on Chang-cells: cells had the lowest initial cell count. Sample 2 had the best protective effect on Chang cells during this experiment.

Figure 2 demonstrates the highly significant protective effect of sample 2 on the pRSV-T cells. After the maximum exposure of the cells to dry air nearly a rate of $100 \%$ cell viability was assessed. On the contrary, the cells incubated with sample 6 lost continuously their viability and thus do not impress with any protective effect.

For additional validation of results the LIVE/DEAD® Viability/ Cytotoxicity Kit was performed with similar findings in both cell lines. Sample 2 had greatest amount of viable cells compared to the other tear substitutes, while sample 6 had significantly lower rates of viable cells.

\section{Discussion:}

This study was performed to evaluate the protective effect of hyaluronic acid on human conjunctival (Chang) and corneal cells (pRSV-T) in an experimental cell culture model. The chosen artificial tears all contain hyaluronic acid in different concentrations and two different buffer systems. Sample $2(0.3 \%)$, compared to sample $1(0.1 \%)$, which consists of the same additives and only differs in concentration of hyaluronic acid, provides the best protection against desiccation even at maximum exposure at 45 minutes, in particular for the corneal cells. It contains the highest to tested concentration $(0.3 \%)$ and most closely resembles normal human tear film in terms of osmolarity, $\mathrm{pH}$ and ratio of electrolytes $(2,6,11)$. Even after increasing drying time up 45 minutes, no further cell loss was observed. This implies that the higher the concentration of hyaluronic acid, the better the protective effect against desiccation.

Incubation with sample 6 lead to loss of viable cells at 0 minutes in both alamarBlue ${ }^{\circledR}$ and LIVE/DEAD $®$ Viability/ Cytotoxicity Kit. This could be due to lack of protective properties, but more likely due to immediate cytotoxic effect during the twenty minute application time.

Generally speaking, samples $1-5$ had similar survival rates throughout this study. This is due to similar pharmacological properties. The molecular weight and osmolality of each product lead to the shown differences.

Generally speaking, samples $1-5$ had similar survival rates throughout this study. This is due to similar pharmacological properties. The molecular weight, osmolality and viscosity of each lead to the shown differences. The composition of sample 6 was unknown, but it was apparent that it had a higher viscosity. The difficulties in removing the solution after application and the consequential higher mechanical cell loss could also be an explanation for the lower survival rates. All samples except sample 6 had highest protective effects at 15 minutes of stress exposure.

The cell model was performed previously and was found to be suitable to assess cytotoxic effects of wetting agents. Various preserved and unpreserved products were tested in studies, but none of them 
containing hyaluronic acid. The tested agents had lower survival rates compared to the samples in this study.

Previous studies showed that hyaluronic acid has a positive effect on dry eyes. $(4,9)$. It was also observed that combinations with trehalose (10) or vitamin B12 (5) were more protective then simple hyaluronic acid and lead to reduction of inflammatory processes due to synergistic effects.

A conjunctival and corneal cell line was used in this study $(1,8)$. The different cell reaction lead to conclude that in vivo the different parts of the ocular surface will also present with different reactions. Cell cultures cannot predict exactly the reactions in vivo due to lack of consideration of blood supply, drug effusion and mucin production. Furthermore it is impossible to consider the physiological interactions on the ocular surface in vitro, hence further clinical evaluation is needed here.

\section{Conclusion:}

The results suggest that high concentrations of hyaluronic acid (sample 2 hyaluronic acid $0.3 \%$ ) and an ionic composition to the normal tearfluid in artificial tears provide the best protective effect against in vitro desiccation. Additive clinical trials are needed for further validation.

\section{Abbreviations}

not applicable

\section{Declarations}

\section{Ethical approval and consent to participate}

not applicable

Consent for publication

not applicable

Availibilty of data and materials

Datasets used and analysed during the current study are available from the corresponding author on reasonable request. All data generated and analysed during this study are included in this published article and its supplementary information files.

\section{Competing interests}

The authors declare that they have no competing interests.

\section{Funding}


This study was funded and the used solutions were provided by Optima Pharmazeutische GmbH.

Authors contributions

AF generated and interpretated the data and worte the manuscript. FT was a major contributor in writing the manuscript. RG performed the statistical analysis of the data. All authors read and approved the final manuscript.

\section{Acknoeledgements}

not applicable

We acknowledge support for the Article Processing Charge from the DFG (German Research Foundation, 393148499) and the Open Access Publication Fund of the University of Greifswald.

\section{References}

1. Doughty MJ, Hagan S. On the staining of human tissue-cultured (Chang) conjunctival cells with rose Bengal stain and lissamine green. Cont Lens Anterior Eye. 2013;36:32-40.

2. Heidinger A, Schmut O, Wedrich A. Synthetische Tränen-Ein Schritt näher der menschlichen Tränenflüssigkeit. Spektrum Augenheilkd. 2015;29:92-8.

3. lester M, Orsoni GJ, Gamba G, Taffara M, Mangiafico P, et al. Improvement of the ocular surface using hypotonic $0.4 \%$ hyaluronic acid drops in keratoconjunctivitis sicca. Eye. 2000;14:892-8.

4. López-García JS, García-Lozano I, Rivas L, Ramírez N, Raposo R, et al. Autologous serum eye drops diluted with sodium hyaluronate: clinical and experimental comparative study. Acta Ophthalmol. 2014;92:22-9.

5. Macri A, Scanarotti C, Bassi AM, Giuffrida S, Sangalli G, et al. Evaluation of oxidative stress levels in the conjunctival epithelium of patients with or without dry eye, and dry eye patients treated with preservative-free hyaluronic acid $0.15 \%$ and vitamin B12 eye drops. Graefes Arch Clin Exp Ophthalmol. 2015;253:425-30.

6. Messmer EM. Das Trockene Auge Medikamentöse Augentherapie. 2017;8:159-70.

7. Oh HJ, Li Z, Park S, Yoon KC. Effect of Hypotonic $0.18 \%$ Sodium Hyaluronate Eyedrops on Inflammation of the Ocular Surface in Experimental Dry Eye. J Ocular Pharmacol Ther. 2014;30:53342.

8. Paduch R, Wozniak A. The Effect of Lamium album Extract on Cultivated Human Corneal Epithelial Cells (10.014 pRSV-T). J Ophthalmic Vis Res. 2015;10:229-37.

9. Pinto-Fraga J, Lòpez-de la Rosa A, Blàzquez Arauzo F, Rodríguez RU, Gonzàlez-García MJ. Efficacy and Safety of $0.2 \%$ Hyaluronic Acid in the Management of Dry Eye Disease. Eye Contact Lens. 2017;43:57-63. 
10. Schmidl D, Schmetterer L, Witkowska KJ, Unterhuber A, dos Santos VA, et al. Tear Film Thickness after Treatment With Artificial Tears In Patients With Moderate Dry Eye Disease. Cornea. 2015;34:421-6.

11. Tiffany JM. The normal tear film. Dev Ophthalmol. 2008;41:1-20.

12. Tost $F$, Keiss R, Großjohann R, Jürgens $C$, Giebel J. Effect of different artificial tears against desiccation in cultured human epithelial cells. Med Sci Monit. 2012;18:188-92.

13. Tseng CL, Hung YJ, Chen ZY, Fang HW, Chen KH. Synergistic Effect of Artificial Tears Containing Epigallocatechin Gallate and Hyaluronic Acid for the Treatment of Rabbits with Dry Eye Syndrome. PLoS One. 2016;11:1-18.

\section{Figures}

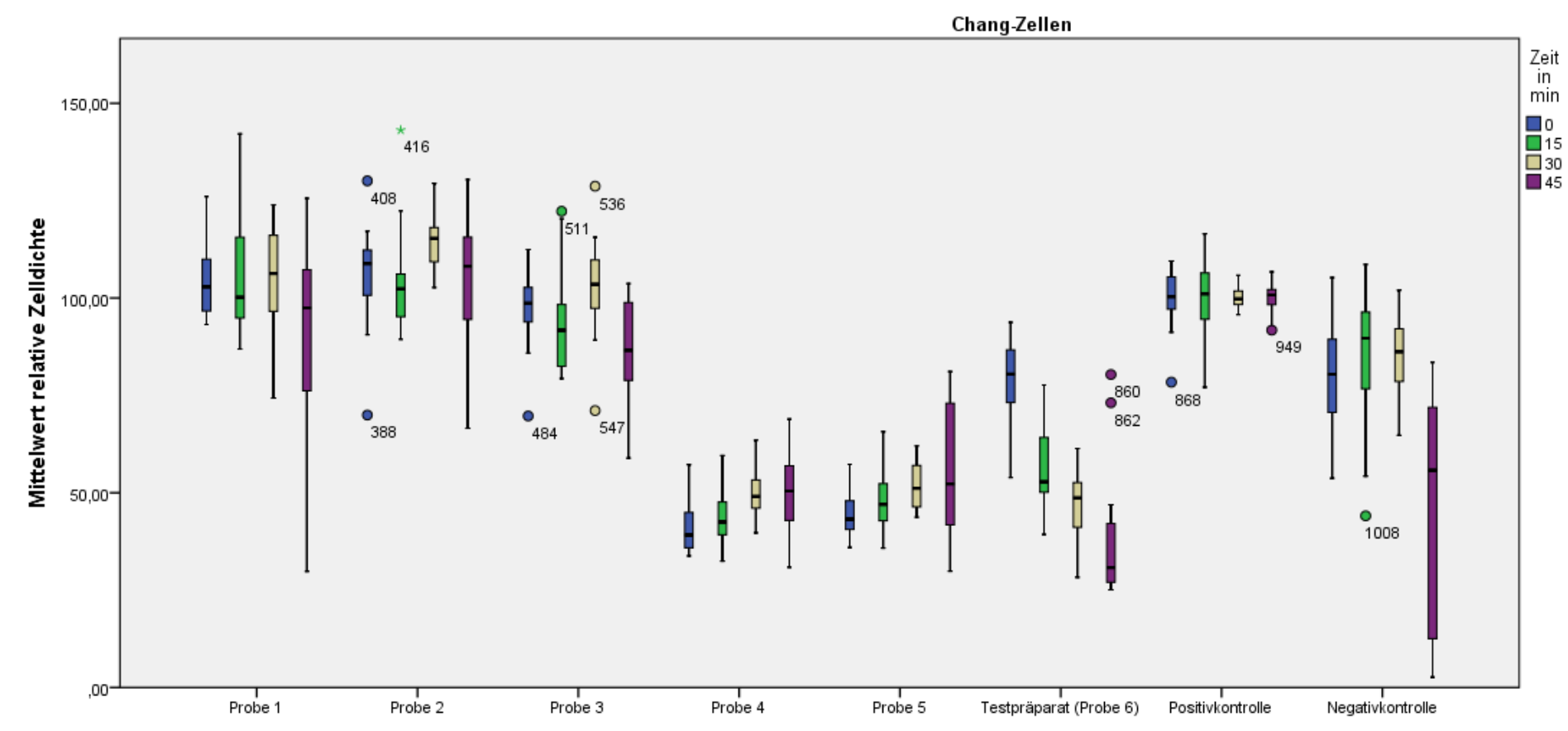

\section{Figure 1}

The mean of cell viability of Chang cells are shown for all samples for $0,15,30$ and 45 minutes. Sample 2 had the greatest protective effect against desiccation, while sample 4, 5 and 6 had similar low amount of viable cells. 


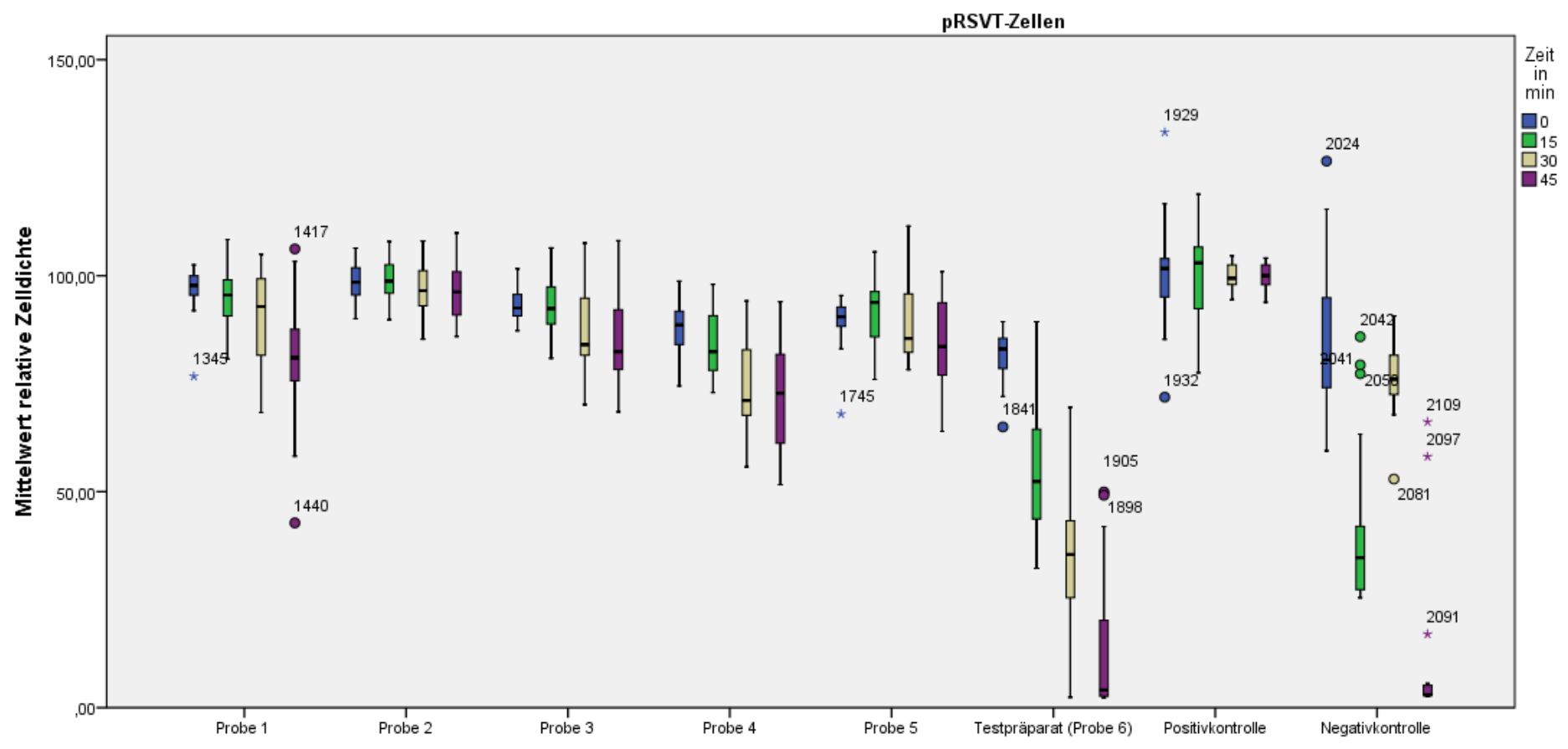

Figure 2

The mean of cell viability of pRSV-T cells are shown for all samples for $0,15,30$ and 45 minutes. Sample 2 had no remarkable loss of viable cells, while in contrast sample 6 has continuous loss of cells and thus no protective effects against desiccation.
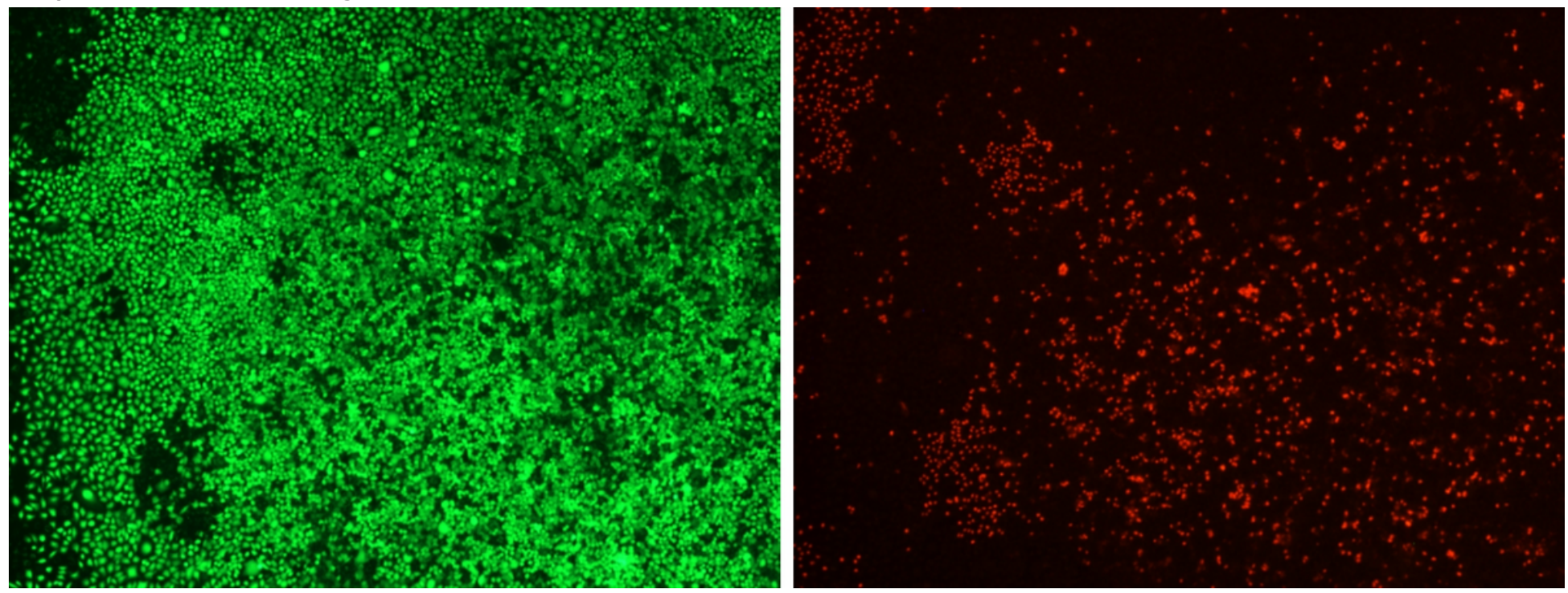

\section{Figure 3}

This figure shows vital (greenish) and avital (reddisch) cells of the conjunctival cell line after application of sample 2 after 30 minutes exposure. The cell count of viable cells significantly outweighs the number of avital cells. 